\title{
AMOR REBELDE: HISTÓRIA, CASAMENTO E POLÍTICA NO ALTO JURUÁ
}

José Pimenta ${ }^{1}$

${ }^{1}$ Universidade de Brasília, Departamento de Antropologia, Brasília/DF, Brasil

\section{Introdução}

Os Ashaninka ${ }^{1}$ são a população nativa mais numerosa da Amazônia peruana e um dos principais povos indígenas da bacia amazônica. Somam hoje mais de 100 mil pessoas no Peru, enquanto menos de 2 mil vivem no estado brasileiro do Acre, na região do Alto Juruá. ${ }^{2}$ Essa extrema desigualdade demográfica entre Brasil e Peru decorre de contingências históricas e da geopolítica dos dois Estados-nações na demarcação de sua fronteira internacional. Em terras brasileiras, a maior parte dos Ashaninka vive na Terra Indígena Kampa do Rio Amônia, um afluente de margem esquerda do rio Juruá, na aldeia Apiwtxa e nos seus arredores, onde totalizam cerca de 800 pessoas.

A partir da década de 1990, os Ashaninka do Amônia objetivaram sua "cultura" (Carneiro da Cunha 2009) e adquiriram uma visibilidade política inédita no campo do indigenismo e do ambientalismo contemporâneo. Nos últimos anos, tenho direcionado o meu interesse etnográfico para entender a história e a política interna e externa deste coletivo. Nas páginas que se seguem, dedico-me à análise de um acontecimento que marcou profundamente a história dos Ashaninka do Amônia e teve consequências políticas importantes para este grupo: o casamento interétnico entre um homem indígena e uma mulher branca.

Se a relação entre casamento e política é um tema clássico da antropologia e a questão da aliança suscitou uma ampla literatura nas terras baixas sul-americanas, a etnologia amazônica tem dado pouca atenção aos casamentos interétnicos, aqui entendidos como uniões entre indígenas e não indígenas. Nas raras vezes em que este tema ganhou algum destaque, o gênero, como veremos, apareceu como um componente marcante. Trata-se, 
sempre, de matrimônios que unem mulheres indígenas a homens brancos. Além disso, esses casamentos ocorrem geralmente nas cidades onde o casal vive ou passa a viver. Contrariamente aos casamentos interétnicos mais comuns que unem homens brancos e mulheres indígenas, o matrimônio do qual tratarei aqui se singulariza por um arranjo invertido, ou seja, a união de um homem indígena e uma mulher branca regional. De forma pouco usual neste tipo de casamento, o casal também passou a viver na comunidade indígena e não na cidade.

Este artigo não pretende discutir a teoria do parentesco nas terras baixas sul-americanas, nem o lugar da afinidade nas sociologias indígenas. Em vez disso, se dedica à análise de uma aliança matrimonial atípica. Procura mostrar sua importância na história dessa comunidade indígena, desvendar seus significados para os brancos da região e para os Ashaninka do Amônia, assim como seus efeitos políticos. Esse matrimônio peculiar apresenta não só uma configuração bastante singular no panorama etnográfico das terras baixas, como também desafia a construção do imaginário nacional brasileiro. Sustento que tal casamento edificou as bases sobre as quais esse coletivo indígena construiu, pouco a pouco, um novo caminho para seu futuro. Neste sentido, ele também fornece uma chave para entendermos o protagonismo e a visibilidade política que os Ashaninka do Amônia adquiriram nas últimas décadas no campo do indigenismo.

Os dados etnográficos resultam de pesquisas acumuladas ao longo de mais de 17 anos entre os índios do Amônia. Procedem, principalmente, de uma etapa de campo realizada em janeiro e fevereiro de 2014, durante a qual tive a oportunidade de aprofundar o meu conhecimento da história das famílias de Samuel Piyãko e Chico Coló, respectivamente, pais do casal Antônio Piyãko e Francisca Oliveira da Silva, conhecida regionalmente como Pití e doravante referida como tal. Antônio, um homem ashaninka, e Pití, uma mulher branca da região, são os principais protagonistas e o casamento que os uniu é o objeto central deste artigo. Este matrimônio também oferece uma oportunidade valiosa para refletir sobre a história dessa região. A história passada das duas famílias me foi narrada, sobretudo, por Antônio e Pití, mas também pelos seus filhos e alguns irmãos e irmãs do casal. Antes de apresentar a trajetória dessas duas famílias, mostrar os acontecimentos que levaram à concretização dessa união tão peculiar, desvendar seus significados e apresentar suas consequências políticas para os Ashaninka do rio Amônia, faz-se necessário desconstruir alguns equívocos sobre a história desse povo indígena no Alto Juruá, principalmente, no rio Amônia. 


\section{Repensando a história do rio Amônia: Ashaninka, "brabos", seringueiros e caucheiros no Alto Juruá}

Excluindo as raras expedições ocorridas ao longo século XIX para explorar a região, a história do Alto Juruá é geralmente apresentada como tendo começado com a chegada dos seringueiros de origem nordestina, a partir da década de 1890. Vindos principalmente do Ceará e atraídos pelas promessas de desenvolvimento da economia da borracha, os seringueiros formaram os primeiros núcleos populacionais não indígenas e são considerados os "desbravadores" do Alto Juruá (Pimenta 2015a). Não existem registros arqueológicos sobre a região, mas a historiografia nos informa que, no auge da economia da borracha, ou seja, entre 1890 e 1912, esse território já era habitado por diferentes povos indígenas, em especial da família linguística Pano, mas também pelos Ashaninka, povo Arawak que durante muito tempo foi chamado Campa no Peru ou Kampa no Brasil.

De modo geral, os historiadores do Acre datam a presença ashaninka na região hoje brasileira do Alto Juruá do final do século XIX ao início do século XX. O padre francês Jean-Baptiste Perrissier, em viagem apostólica ao Alto Juruá em 1897 e 1898, foi o primeiro ocidental a registrar a presença desse povo no rio Amônia; índios que o autor apresenta erroneamente como "os antigos Incas do Peru" (Perrissier 2009 [1898]:56). Assim, a tese mais comum, para não dizer a única, afirma que os Ashaninka, originários do Peru, foram trazidos por patrões caucheiros daquele país juntamente com outros povos indígenas, como os Kaxinawá (Huni Kuin), a partir do final do século XIX. Se não há dúvidas sobre a exploração caucheira ter contribuído para a migração de várias famílias ashaninkas para o Alto Juruá brasileiro, outras hipóteses, que independem dos brancos, também devem ser consideradas.

Em outra ocasião, tive a oportunidade de questionar alguns mitos fundadores da história oficial do Acre (Pimenta 2015a). Mesmo quando procura resgatar outras visões de mundo, a história ocidental tende a considerar os brancos como os principais protagonistas dos acontecimentos e os povos indígenas como vítimas passivas. Ao contrário, a etnologia das terras baixas, pelo menos nos últimos trinta anos, tem procurado enfatizar a agência indígena e apresentar uma visão mais complexa dos fenômenos históricos.

Assim, diversas etnografias mostraram que as trajetórias históricas dos povos amazônicos são muito variadas e se caracterizam por uma importante mobilidade, decorrente de fatores diversos que remetem a causas exógenas e a dimensões internas de cada sociedade indígena. Contra os adeptos da ecologia cultural, Balée (1994), por exemplo, a partir de seu trabalho entre os Ka'apor, mostrou que parte significativa da floresta amazônica é antropo- 
gênica, produto da atividade secular dos povos indígenas que tiveram um papel essencial na modelagem da paisagem e no enriquecimento da biodiversidade da região, antes de sofrerem o colapso demográfico pós-conquista e intensificarem suas migrações. Embora a ecologia histórica de Balée tenha mostrado os equívocos do determinismo ambiental, por outro lado, ela é insuficiente para explicar a mobilidade dos povos indígenas amazônicos, que não pode ser reduzida a adaptações históricas pós-coloniais.

Os Huaorani do Equador oferecem um excelente exemplo de uma sociedade indígena cuja intensa mobilidade não resulta nem de determinismos ecológicos, nem de arranjos históricos decorrentes do impacto da colonização, mas de escolhas políticas e culturais dos próprios índios (Rival 2002). Um único povo, mesmo demograficamente pouco numeroso, também pode viver processos históricos e migratórios muito distintos. É o caso, por exemplo, dos Parakanã. Ao analisar a história de dois grupos Parakanã - oriental e ocidental - que, juntos, somam atualmente cerca de 1.500 pessoas, ${ }^{4}$ Fausto (2001) mostrou que esses dois blocos se caracterizam por trajetórias históricas diametralmente opostas não somente em seus padrões de assentamento e modos de subsistência, mas também em suas formas de organização política e reprodução social.

Esses exemplos são suficientes para mostrar que as histórias das sociedades indígenas amazônicas apresentam uma grande diversidade de situações e não podem ser explicadas única e exclusivamente por fatores exógenos. Os povos indígenas tiveram sua história modelada por diferentes processos históricos, antes e depois da chegada dos brancos, mas também imprimiram sua marca nesses processos. Dessa forma, sem negligenciar as forças socioeconômicas do período da borracha que mudaram profundamente a história e a demografia do Alto Juruá a partir do final do século XIX, a vinda dos Ashaninka para o rio Amônia não deve ser considerada apenas como decorrente da ação dos brancos e da pressão colonial sobre seu território, como apresenta a historiografia da região. Não cabe aqui mapear com exatidão os percursos históricos dos Ashaninka do rio Amônia, cujos deslocamentos diminuíram sensivelmente com a demarcação de sua terra indígena no início da década de 1990. O que importa é salientar outros fatores que também motivaram esses movimentos. Embora a história da ocupação do rio Amônia ainda levante muitas dúvidas, os relatos orais dos Ashaninka sobre sua chegada à região convidam-nos a um olhar menos etnocêntrico e a uma maior modéstia na nossa abordagem da história local.

Em suas narrativas, os Ashaninka sempre se posicionam como os principais atores de sua própria história. Desse modo, para explicar sua instalação no Amônia, relatam processos complexos e multifacetados, caracterizados 
por uma intensa mobilidade, sucessivas migrações, envolvendo muitas idas e vindas motivadas por diversos fatores. Os grupos familiares que vivem hoje no Amônia provêm de diferentes lugares e experimentaram processos migratórios dinâmicos e variados. Existem, por exemplo, laços de parentesco que unem os Ashaninka do Amônia a outros ashaninkas localizados tanto em território peruano como em outras terras ashaninkas no Brasil, principalmente nos rios Breu e Envira. Ao longo dos últimos cem anos também ocorreram migrações entre o Peru e o Brasil, deslocamentos populacionais do Envira e Breu em direção ao rio Amônia e em sentido contrário.

Os Ashaninka explicam essas migrações em função de vários fatores: agrupamentos familiares, escassez de recursos naturais de um determinado ecossistema, trocas e comércio, alianças políticas, disputas internas, mortes de parentes, busca por um "bom patrão"5 ou, simplesmente, pelo desejo de conhecer outros lugares. Alegam, ainda, valores éticos de sua sociedade. Neste sentido, a migração é também uma expressão do apego à ideia de liberdade, uma aspiração constante na história desse povo.

É importante salientar que as narrativas indígenas não mencionam os brancos para explicar a vinda dos primeiros ashaninkas para o rio Amônia. As migrações iniciais são apresentadas por meus interlocutores como o resultado da iniciativa de algumas famílias pioneiras que passaram a usar esse rio inicialmente como território de pesca, caça e coleta. Para explicar essas migrações, vários depoimentos destacam simplesmente a adequação desse rio aos seus "costumes", em especial o gosto de viajar e as características geográficas e ambientais do lugar, isto é, um território naquele momento não ocupado por brancos, com uma floresta rica em caça, um rio abundante em pesca e com belas praias que favorecem o acampamento no período estival, época em que os Ashaninka procuram ovos de tracajá, um alimento altamente valorizado.

Os índios do rio Amônia afirmam que Kentsironki, pai de Kamerentsi, este último também conhecido pelo apelido português de "Tenente", foi o primeiro ashaninka a estabelecer residência permanente no Amônia. Kentsironki teria vindo do rio Sheshea, um afluente do Ucayali, no final do século XIX, e passou a residir no alto ${ }^{6}$ Amônia, num lugar chamado Nowaya, que os meus interlocutores situam perto das cabeceiras do rio, em território peruano. Descendentes desse grupo familiar moram hoje na Terra Indígena Kampa do Rio Amônia.

Assim, a história oral indígena indica que, no final do século XIX, alguns ashaninkas já percorriam o rio Amônia, principalmente no período estival para suas atividades de caça, pescaria ou de coleta de ovos de tracajá; uma dessas famílias optou por se estabelecer no alto curso desse rio, cuja foz 
começava a ser disputada por seringueiros brasileiros e caucheiros peruanos. Para os Ashaninka, o Amônia ainda não contava com a presença de brancos e era uma via fluvial importante que possibilitava a conexão entre as bacias dos rios Juruá e Ucayali. Subindo o Amônia, várias trilhas na floresta permitem o acesso aos rios Sheshea e Tamaya, afluentes do Ucayali. Progressivamente, de território de passagem e de ocupação temporária, o Amônia tornou-se um local de residência permanente para alguns ashaninkas, reconhecendo-se o grupo familiar de Tenente pelo pioneirismo dessa iniciativa, provavelmente, no final do século XIX.

Naquela época, segundo os relatos dos meus interlocutores, o médio e alto Amônia eram frequentados somente por povos indígenas. Além dos próprios ashaninkas, alguns deles mencionam vagamente a presença dos Kaxinawá e Santa Rosa. As informações sobre esses dois povos são pouco precisas, mas são atribuídos a eles alguns vestígios cerâmicos encontrados na região. Os Ashaninka lembram, sobretudo, dos Amahuaca, um povo de língua pano que vive atualmente no lado peruano da fronteira e cuja presença na região do Alto Juruá brasileiro também é mencionada em documentos históricos no início do século XX. No entanto, para os Ashaninka do Amônia, a palavra "amahuaca" é usada como uma categoria genérica para se referir aos "índios brabos" que, em contraste com eles próprios, habitam o interflúvio, vivem no meio da floresta, não usam canoa, praticam a antropofagia e "andam nus". ${ }^{7}$ Os Amahuaca propriamente ditos são apenas um arquétipo desses "índios brabos", considerados inimigos tradicionais e, na época, uma ameaça permanente para os Ashaninka. Roubavam suas roças e, na ausência dos moradores, arriscavam-se nas proximidades das habitações, furtavam frutas nos quintais e saqueavam as casas. Junto com o seu pai, Tenente é lembrado pelos Ashaninka por ter afugentado os Amahuaca no rio Amônia.

Com a instalação progressiva da economia da borracha, esses índios "brabos" também ameaçavam a exploração dos seringais. Para assegurar a colonização da região, patrões seringalistas e caucheiros peruanos, como Julio Peres, organizavam incursões punitivas contra eles. Essas expedições, conhecidas como correrias, são tema recorrente em toda a bibliografia sobre a abertura dos seringais e o auge da economia da borracha no Alto Juruá (ver, por exemplo, Iglesias 2010). Por vezes, os patrões adotavam uma estratégia de conquista bem conhecida: usando as hostilidades tradicionais, abasteciam os Ashaninka e outros povos indígenas, como os Kaxinawá, com mercadorias e os armavam nas correrias contra os "brabos". Apreciados por sua fama guerreira, os Ashaninka serviram, assim, aos desejos dos patrões brancos, ao mesmo tempo em que satisfaziam seus próprios interesses, eliminando os índios "brabos" da região. No Alto Juruá, de modo geral, e no rio Amônia, em 
particular, os Ashaninka não deixaram de desempenhar um papel importante na exploração da borracha, não tanto como mão de obra extrativista, mas principalmente, como dizem, como "guardiões dos seringais".

Durante as primeiras décadas do século XX, os Amahuaca foram sendo dizimados pelas correrias ou apenas fugiram da região. Feitas cativas, algumas de suas mulheres foram incorporadas à sociedade ashaninka. Este foi o caso de Margarida, que conheci no ano 2000. Com cerca de 90 anos na época, Margarida era a índia mais idosa da aldeia Apiwtxa dos Ashaninka do rio Amônia. Meus anfitriões contavam que ela era amahuaca, identidade que ela mesma confirmava com certo embaraço. Pouco sabiam de sua história e ela própria apresentava relatos muito desconexos de sua vida passada. Diziam que sua mãe tinha sido capturada grávida dela na cabeceira do rio Amônia e depois "amansada", ou seja, incorporada ao modo de vida ashaninka, pelo pai de Tenente, do qual se tornaria esposa. Margarida já nasceu entre os Ashaninka e foi criada pela família de Tenente, casando-se, mais tarde, com Pedrilho, um tio de Antônio Piyãko, irmão de sua mãe, Mariwãtxo. Faleceu em 2007 e, mesmo tendo nascido e vivido entre os Ashaninka a vida inteira, nunca deixou de ser vista como Amahuaca.

Assim, a partir dos relatos ashaninkas, a história oficial do Alto Juruá merece ser problematizada e complexificada para desconstruir uma visão eurocêntrica que, quando não simplesmente oculta sua presença na região, apresenta-os como um povo indígena vindo do Peru que migrou para o Brasil no final do século XIX ou início do XX, trazidos ou pressionados por caucheiros peruanos. A presença de patrões da borracha certamente não é irrelevante nos deslocamentos ashaninkas. Veremos, na próxima seção, que a busca por um "bom patrão" foi um dos fatores que motivaram a vinda de Samuel Piyãko e de seu sogro para o Brasil. No entanto, do ponto de vista dos índios, os brancos não são mencionados para justificar as primeiras migrações dos Ashaninka para o rio Amônia. Ora, não só a história do Alto Juruá liga a presença desse povo indígena no Alto Juruá à única iniciativa dos caucheiros, como também é bastante comum ouvir, ainda hoje, que os Ashaninka são "descendentes dos Incas", como afirmava Perrissier há mais de um século ou, simplesmente, "índios peruanos", alegações totalmente equivocadas que por vezes visam questionar a legitimidade de seus direitos constitucionais em solo brasileiro. Embora o argumento do pioneirismo e da anterioridade na ocupação do rio Amônia não tenha nenhum respaldo jurídico, ${ }^{8}$ os Ashaninka gostam de lembrar que não foram eles que vieram para o Brasil, mas o Brasil é que incorporou um território no qual eles já estavam presentes e consideravam como seu. De fato, o rio Amônia ainda não fazia parte do Brasil nos primeiros anos do século XX. 
Na história oral indígena, transmitida de geração a geração, encontramos várias referências ao conflito armado de setembro de 1904, que opôs seringueiros brasileiros e caucheiros peruanos no controle da "boca do Amônia". Conhecido na literatura como "Batalha do Amônia", o conflito ocorreu no pequeno povoado situado na confluência com o rio Juruá (Tocantins 1979:396-405). Com a vitória dos seringueiros brasileiros, o povoado de Nueva Iquitos, onde os peruanos tinham instalado um posto aduaneiro para recolher impostos sobre a produção de borracha, passou para o controle brasileiro e foi rebatizado como Distrito Thaumaturgo, posteriormente, Vila Thaumaturgo e, desde 1992, município Marechal Thaumaturgo. ${ }^{9}$

O Tratado de Petrópolis de 1903, assinado entre o Brasil e a Bolívia, é geralmente tido como a certidão de nascimento do Acre, mas o litígio fronteiriço entre Brasil e Peru no Alto Juruá só foi resolvido em setembro de 1909 com a assinatura do Tratado de Rio de Janeiro. Na alvorada do século XX, a foz do rio Amônia era disputada por caucheiros peruanos que desciam o rio Juruá e por seringueiros brasileiros que subiam o mesmo rio. No médio e alto Amônia viviam somente índios. Os Ashaninka moravam no alto Amônia e o curso médio do rio era habitado pelos Amahuaca. Embora não houvesse moradores ashaninkas no médio Amônia, essa parte do rio já era considerada por eles um território de caça, pesca e coleta que frequentavam periodicamente. É importante frisar que, naquela época, essa porção de rio nem brasileira era.

\section{Duas famílias no rio Amônia: Samuel Piyãko e Chico Coló}

Enquanto as informações sobre a família de Tenente e seu pai ainda carecem de precisão, a trajetória da família Piyãko, principal grupo familiar da aldeia Apiwtxa, pode ser reconstruída com maior segurança. Samuel Piyãko faleceu em 1987. Ele era avô dos principais líderes da Apiwtxa e pai de Antônio Piyãko, considerado pelos brancos como o "chefe tradicional" ou curaca dos índios do rio Amônia.

Samuel saiu do Alto Ucayali com cerca de 18 anos de idade. Teria trabalhado por um curto período num alambique no Baixo Ucayali antes de ir para o rio Sheshea, onde conheceu um ashaninka chamado Agostinho, originário do rio Tambo. Este último contou-lhe que sua filha Mariwãtxo (Mariquinha em português) tinha sido levada a contragosto por um ashaninka para o Alto Juruá peruano. Agostinho, então, desafiou Samuel para trazer-lhe a filha de volta, prometendo oferecê-la em casamento, caso conseguisse a empreitada. Samuel aceitou o desafio. Foi buscar Mariwãtxo e a devolveu 
aos pais. Ela se tornaria sua primeira esposa. O casal teve nove filhos. Os dois primeiros, Paulo e Kumayé, nasceram ainda no rio Sheshea, no Peru; os outros, entre eles Antônio, já nasceram no Amônia. Alguns anos mais tarde, Samuel também se casou com Amélia, uma irmã mais nova de Mariwãtxo. Com duas esposas, Samuel viveu uma situação de poliginia sororal pouco frequente, mas não excepcional entre os Ashaninka.

Os meus interlocutores do rio Amônia afirmam que Samuel e seu sogro não vieram para o Brasil fugindo de patrão ou trazidos por caucheiros. Vieram, dizem, em busca de "um bom patrão" para "fazer comércio" ou "trocar". Souberam que, no Brasil, patrões trocavam mercadorias por caucho e peles de animais silvestres. Dizem também que muitas doenças assolavam a região peruana do Ucayali e seus afluentes em razão da presença dos caucheiros. Uma epidemia de sarampo teria sido um motivo adicional para buscar, em território brasileiro, um lugar de moradia mais seguro e com maiores oportunidades para obter bens industriais.

Assim, no final da década de 1930, Samuel e o sogro decidiram cruzar a fronteira e explorar a região brasileira do Alto Juruá em busca de um lugar para a família se estabelecer. Do Sheshea foram para o rio Vacapistea, um afluente do Juruá, desceram este último, passaram pela foz do Breu e subiram o Amônia até encontrar a família de Tenente morando no alto deste rio. Durante essa viagem exploratória, os dois homens encontraram no curso médio do rio Amônia um ambiente ideal para morar.

Após essa primeira viagem, Samuel e o sogro retornaram ao Peru para buscar o restante da família, umas sete ou oito pessoas, segundo os relatos. Estabeleceram-se definitivamente no médio rio Amônia por volta de 1940. Os Ashaninka dizem que Samuel escolheu, inicialmente, a boca do igarapé Cachoeira (Txowentawo) para morar com sua família, mas mudou várias vezes seu lugar de residência, ocupando, assim, praticamente toda a área do médio rio Amônia. Mesmo com essas mudanças frequentes, Samuel Piyãko sempre permaneceu no curso médio do rio Amônia, na área hoje demarcada como terra indígena.

Após a instalação do grupo de Samuel, outras famílias ashaninkas, como as famílias de Homo e Parota, chegaram ao rio Amônia nos anos e décadas seguintes, enquanto outros se retiraram. Os fluxos migratórios continuam até hoje, variando consideravelmente em função da conjuntura histórica e dos anseios de cada família. Houve, por exemplo, do final da década de 1980 até o início dos anos 1990, a chegada de algumas famílias vindas do Peru, fugindo dos movimentos de luta armada do Sendero Luminoso e do Movimento Revolucionário Tupac Amaru. A partir de 1992, a demarcação da terra indígena introduziu progressivamente uma nova concepção do território 
como um espaço delimitado, diminuindo as migrações transfronteiriças, sem anulá-las totalmente. A atual população da Terra Indígena Kampa do Rio Amônia é, assim, resultado de diversos fluxos migratórios que ocorreram principalmente ao longo do século XX.

Segundo os Ashaninka, a decisão de Agostinho e Samuel de morar no curso médio do rio Amônia não foi fortuita. Resultou de uma clara consciência histórica e política diante da situação de contato com os brancos. Embora os Ashaninka relatem que Samuel, junto com Tenente, ainda tenha participado de algumas correrias contra os últimos amahuacas da região, na década de 1940, a ameaça dos índios "brabos" não constituía mais um real problema no rio Amônia. Além da abundância de recursos naturais e das características topográficas adequadas aos padrões culturais e ao modo de vida ashaninka, o médio Amônia, contrariamente ao baixo, era uma terra sem seringa e, portanto, sem a presença de brancos, um fator determinante na escolha de Samuel e seu sogro para fazerem dessa porção de rio seu local de moradia.

Apesar de visitas esparsas de alguns brancos para caçadas e pescarias, nenhum destes residia no médio Amônia, o que oferecia aos Ashaninka uma dupla vantagem: estavam, ao mesmo tempo, suficientemente distantes dos brancos para evitar a opressão da economia extrativista da seringa e relativamente próximos dos patrões para possibilitar a troca de produtos e a aquisição dos bens manufaturados desejados. Com essa localização ideal, os Ashaninka aspiravam alcançar o melhor de dois mundos: manter seu modo de vida "tradicional", sem deixar de ter acesso às mercadorias ocidentais. Após o auge da economia da borracha e das correrias, as relações interétnicas que os Ashaninka do Amônia estabeleceram com os brancos regionais foram sempre guiadas por este duplo objetivo.

A avó materna de Pití, Antônia Paiva, chegou aos 13 anos à região do Alto Juruá com seus pais. A família vinha do Ceará para trabalhar nos seringais no apogeu da economia da borracha. Seu avô materno, Manuel Soares de Oliveira, era baiano e também sucumbiu à atração do "ouro branco" e às promessas de riqueza que ele propiciava. Antônia e Manuel casaram-se no então Seringal Minas Gerais, na boca do rio Amônia, e tiveram nove filhos, dentre eles, Cleunice Soares de Oliveira, regionalmente conhecida como Nega Soares, mãe de Pití.

A avó paterna de Pití, Clotilde Munis, também originária do Ceará, migrou para a região de Tefé no Amazonas, onde trabalhou como lavadeira. Casou-se com um pescador local, Francisco Fortunato da Silva, com o qual teve dois filhos, uma menina e seu irmão mais novo, Francisco Chagas Munis da Silva. Este último nasceu possivelmente em 1920. Passou a ser conhecido como Chico Coló. É o pai de Pití. Depois de alguns anos, Francisco Fortu- 
nato da Silva abandonou a família e foi morar em Manaus. Clotilde foi para Cruzeiro do Sul com os dois filhos e a mãe, Alexandrina.

Chico Coló chegou à capital do Alto Juruá com cerca de 10 anos de idade. Na adolescência, trabalhou como pescador. No final da década de 1930, com cerca de 18 anos, foi para o Alto Juruá, convidado por um patrão da região para trabalhar na extração da madeira que era encaminhada para Manaus e Belém. Passou também uns dois anos num seringal do rio Tejo. Com cerca de 23 anos, foi morar na Vila Thaumaturgo, onde conheceu Nega Soares, mãe de Pití. Três anos mais velha, ela criava sozinha três filhos, após perder o primeiro marido num acidente. Chico Coló e Nega Soares casaram-se na Vila Thaumaturgo no início da década de 1940, ou seja, aproximadamente na mesma época em que o grupo familiar de Samuel Piyãko se instalava no médio Amônia. Após o casamento, o casal foi morar no baixo rio Amônia juntamente com os pais de Nega Soares, numa localidade denominada Saboeiro. Uns anos depois, subiram o Amônia e foram para o rio Putaya, no Peru, onde também trabalharam na extração de seringa, durante um breve período, para Filemon, um patrão do país vizinho. A mulher de Chico Coló não gostou da vida no Peru e voltaram rapidamente para o baixo rio Amônia. Instalaram-se nas proximidades do Saboeiro, no local conhecido como Palmares, onde, em 1947, nasceu Pití, terceira de dez irmãos (cinco mulheres e cinco homens). Nega Soares e Chico Coló viveram durante a maior parte da vida no rio Amônia, próximos à maioria de seus filhos, saindo somente por curtos períodos para Marechal Thaumaturgo e Cruzeiro do Sul. Nega Soares faleceu em 2001; Chico Coló em 2011, com mais de 90 anos.

\section{Do namoro ao casamento}

A partir de 1912, a primeira crise da economia da borracha afrouxou o domínio dos patrões e os seringueiros passaram a diversificar suas atividades cotidianas, dividindo a produção de borracha com a agricultura, a caça e a pesca, dando origem a um "campesinato da floresta" (Almeida 1993). Durante a Segunda Guerra Mundial, com o aumento temporário da demanda internacional por borracha amazônica decorrente do bloqueio da produção dos seringais asiáticos, o Alto Juruá viveu um curto momento de euforia, antes de a economia gomífera entrar novamente em crise nas décadas posteriores, sobrevivendo apenas com ajuda de subsídios do Estado.

Nas décadas de 1940 e 1950, junto com outras atividades, as famílias brancas do rio Amônia continuaram a se dedicar ao corte de seringa para os patrões regionais, principalmente, para Odon do Vale, no sistema bem 
conhecido do aviamento. Vários relatos contam que a seringa produzida no Amônia era vendida obrigatória e exclusivamente para esse patrão. Os seringueiros também eram obrigados a comprar as mercadorias em seu barracão, na Vila Thaumaturgo, a preços exorbitantes, alimentando um sistema permanente de dívidas.

Todos os depoimentos, tanto dos Ashaninka como de brancos da região, convergem para afirmar que, até meados da década de 1950, os moradores não indígenas ocupavam somente a parte baixa do rio Amônia, onde se situava o antigo seringal Minas Gerais, sendo o restante do rio de domínio dos Ashaninka, após a dizimação e fuga dos Amahuaca. Nessa parte inferior do rio Amônia, próximo à sua foz, vivia uma dezena de famílias brancas, entre elas, a família de Pití.

Os Ashaninka continuaram mantendo relações intermitentes com os brancos regionais baseadas na troca de produtos florestais por mercadorias. O comércio e a guerra sempre foram dois pilares da sociedade ashaninka. Bem antes da chegada dos espanhóis, juntamente com outros povos Arawak subandinos, eles articulavam um vasto sistema de redes comerciais entre as terras baixas e as terras altas e participavam do comércio amazônico com outros Arawak e povos Pano ribeirinhos, no qual o sal era a principal moeda de troca (Renard-Casevitz 1993). Embora nunca tenham sido incorporados como mão de obra servil nas estradas de seringa, com exceção de poucas famílias, no final do século XIX e nas primeiras décadas do XX, os Ashaninka do Alto Juruá brasileiro participaram da extração do caucho e do sistema do aviamento que regulava as transações comerciais na região.

Assim, após atuarem como "guardiões dos seringais" contra a ameaça dos Amahuaca no auge do período da borracha, os Ashaninka integraram as redes de troca da economia local, oferecendo novos serviços aos patrões. A organização e o crescimento populacional dos seringais necessitavam de uma mão de obra externa capaz de abastecer os barracões com alimentos e outros produtos e assegurar o trabalho dos seringueiros nas colocações. Nesse contexto, caucho e madeira, explorados em pequena escala, e animais silvestres (caititu, queixada, jaguatirica, onça etc.), que forneciam carne e peles valorizadas no comércio amazônico, eram trocados por mercadorias industrializadas: terçados, facas, espingardas, munição, panelas etc. Esse intercâmbio ocorria geralmente no próprio rio Amônia, onde patrões e atravessadores iam ao encontro dos índios, que também podiam descer o rio até a Vila Thaumaturgo. Por vezes, os Ashaninka subiam o Juruá até a boca do rio Tejo para trocar com os brancos. Mesmo com o declínio da economia da borracha, os Ashaninka mantiveram praticamente inalterado esse padrão de relações esporádicas de troca com os brancos regionais até a década de 1970. 
Milton, Chico Mariano e Odon do Vale são lembrados como os principais patrões da região durante esse período.

Na década de 1950, com o aprofundamento da crise da borracha, algumas famílias brancas começaram a subir o rio Amônia em busca de áreas mais preservadas e mais ricas em caça e madeira. Progressivamente, instalaram-se em território ashaninka. Thaumaturgo Ferreira, um branco originário do rio Breu, é lembrado como pioneiro desse movimento. Em meados dos anos 1950, ele subiu o rio Amônia e foi morar na boca do igarapé Amoninha, já próximo à fronteira com o Peru, na vizinhança do grupo familiar de Samuel Piyãko. Após uns cinco anos no local, decidiu partir para explorar madeira no rio Tamaya, no Peru. Antes de sair, Thaumaturgo Ferreira convidou Chico Coló, o pai de Pití, para ocupar seu sítio. Em troca, pediu ajuda somente para carregar seus pertences para o Peru. Coló gostou do lugar, pediu autorização a Samuel e, diante do bom acolhimento, mudou-se com esposa e filhos para a boca do igarapé Amoninha, no início da década de 1960. Nessa época, Pití era uma adolescente com cerca de 14 anos.

Chico Coló e Samuel Piyãko conheciam-se há mais de dez anos e mantinham um relacionamento cordial. Ambos trabalharam no corte de madeira para Chico Mariano, um pequeno patrão e atravessador branco da região. Segundo Antônio Piyãko, Chico Coló também conhecia a família de Tenente e respeitava muito os Ashaninka. Antônio diz ainda que, embora tivesse alguns preconceitos contra os "caboclos", Chico Coló não era patrão e nunca considerou os Ashaninka como seres inferiores. Com a proximidade, a relação entre Chico Coló e Samuel Piyãko se estreitou. Tornaram-se amigos, chamavam-se de compadre em português e convidavam-se para beber caiçuma (bebida de mandioca fermentada). As crianças, por vezes, brincavam juntas. Chico Velho, um irmão de Pití, três anos mais novo, tem a mesma idade de Antônio Piyãko. Ambos criaram uma forte amizade que dura até hoje. Assim, as duas famílias passaram a manter estreitos laços sociais. Aos 17 anos, Pití começou o namoro com Antônio, que tinha então 14 anos. Namoraram na calada da noite, às escondidas, durante quase um ano.

Pití diz que nunca teve preconceito em relação aos Ashaninka ou aos "Kampa", nome pelo qual eles ainda continuam sendo chamados na região. Afirma que só conheceu Antônio quando foi morar no igarapé Amoninha, no médio Amônia. No entanto, contou que, desde criança, era fascinada pelos Ashaninka. Ficava impressionada com a postura digna que eles apresentavam ao descer o rio Amônia para comerciar na Vila Thaumaturgo ou na foz do Breu. Do barranco onde morava com a família, ainda nas margens do baixo Amônia, avistava periodicamente Samuel, seu sogro, e outros ashaninkas descendo o rio, em pé em suas canoas, vestindo a kushma, adornados com 
seus chapéus e txoshiki. ${ }^{10}$ Segundo ela, apesar do medo e do preconceito que tinham, todos os brancos achavam linda essa cena. Pití afirma que os Ashaninka sempre foram diferentes dos outros índios da região. Os "Kampa" eram orgulhosos de sua cultura; nunca pediam comida ou dormida, sempre erguendo acampamentos provisórios (tapiri) em alguma praia do rio. Pití contou ainda que, numa ocasião, quando tinha uns 8 ou 9 anos, os Ashaninka acamparam próximo da casa de seus pais e ela, destemida, se aproximou para conversar com as raras mulheres que os acompanhavam. A tentativa foi frustrada; os "Kampa" eram "muito cismados" e "não gostavam de conversar com brancos".

Nega Soares, mãe de Pití, desconfiou do romance e incumbiu uma de suas filhas mais novas de vigiar os namorados. A relação amorosa foi descoberta e a mãe ficou furiosa. Como a grande maioria da população regional, Nega Soares não gostava de índios e não aceitava que uma de suas filhas namorasse um "caboclo sujo e nojento". Para ela, índio "não era gente". No início, o pai de Pití também não se mostrou muito favorável ao namoro mas, aos poucos, diante da determinação da filha, acabou conformando-se.

O pedido de casamento ocorreu em 1965. Esse momento e a cena tragicômica que o caracterizou são hoje rememorados com bom humor pelos protagonistas e suas famílias. Acompanhado de Antônio e de vários ashaninkas armados com arco e flecha e pintados para a guerra, Samuel foi à casa de Chico Coló. Chegando lá, disse ao amigo: "Compadre, quero a sua filha para casar com o meu filho. Se você não me der, eu roubo ela". Acuado, o pai de Pití não pôde recusar o pedido e o aceitou prontamente. No entanto, Nega Soares se recusou a entregar a filha aos "caboclos" e começou uma disputa truculenta entre ela e o marido. Transtornado com a intransigência da mulher, Chico Coló decidiu então se suicidar. Determinado a se enforcar, pegou uma corda que pendurou no galho de uma árvore. Subiu num banco, passou a corda em volta do pescoço, mas, no momento fatídico, o galho quebrou! Os Ashaninka dizem que assistiram a essa cena impassíveis, com um misto de incredulidade e espanto, diante das bizarrices comportamentais dos brancos.

Apesar da negativa e do desgosto de Nega Soares, Antônio e Pití casaram-se oficialmente no dia 19 de janeiro de 1967, durante as festas de novenário, na Vila Thaumaturgo. Casaram-se no Registro Civil e na Igreja Católica, uma exigência de Pití. Como veremos a seguir, o casamento de uma branca com um índio causou espanto e indignação entre os regionais. Pelo simples fato de ele ser índio, Nega Soares levou décadas para começar a apreciar o genro. Somente no fim da vida, reconheceu que Antônio era um "homem trabalhador", um "bom caçador" e que sua filha estava feliz 
no matrimônio. Juntos há mais de meio século, Pití e Antônio tiveram sete filhos, cinco homens e duas mulheres: Francisco, Moisés, Dora, Isaac, Benki, Wewito e Alexandrina.

\section{Um casamento atípico: desafiando convenções sociais e morais}

O tema do gênero tem sido objeto de alguns trabalhos na etnologia amazônica (ver, por exemplo, McCallum 2001) e até de esforços comparativos com a Melanésia (Tuzin \& Gregor 2001). No entanto, a etnologia regional tem dado pouca atenção ao casamento entre indígenas e brancos, com exceção de alguns trabalhos importantes, como os de McCallum (1997) e Lasmar $(2005,2008)$. Mesmo quando tomam os matrimônios interétnicos como foco central de suas análises, estas autoras tratam essencialmente de uniões envolvendo mulheres indígenas e homens brancos. Em sua etnografia, Lasmar (2005:197-212), por exemplo, menciona a existência de alguns casamentos entre mulheres brancas e homens indígenas, mas salienta que este tipo de união é raro e se concentra nos matrimônios, muito mais frequentes, entre mulheres indígenas e homens brancos que residem na cidade de São Gabriel da Cachoeira. Antes de mostrar como o matrimônio de Antônio e Pití foi visto pelos Ashaninka, cabe enfatizar a sua especificidade e a maneira pela qual ele foi considerado pelos brancos da região.

Ao analisar as relações de gênero e a sexualidade entre Kaxinawá e brancos no Acre, McCallum (1997) afirmou que o casamento entre um homem branco e uma mulher indígena reforça a supremacia da conquista ocidental, a desigualdade de gênero e a mitologia da miscigenação da nação brasileira. Já uma relação inversa, ou seja, uma história de amor ou uma relação sexual entre uma mulher branca e um homem indígena, é considerada uma transgressão social tão poderosa que cria um "campo de horrores" (:135, tradução minha). Uma ideia semelhante foi exposta por Ramos (1998:67-69), que considerou que a estrutura dos casamentos entre índios e brancos revela uma assimetria de gênero e o caráter paternalista da sociedade brasileira. Segundo esta autora, no Brasil, com a colonização portuguesa, o casamento de um homem branco com uma mulher indígena foi historicamente estimulado e é socialmente tolerado. Este tipo de união participou da edificação das bases do mito de fundação da nação brasileira, que elogia a mistura harmoniosa das "três raças": branco, índio e negro. No entanto, nessa idealização da nacionalidade, como dizem os ditados populares, é sempre a avó (nunca o avô) que é "apanhada a laço" ou a "dentes de cachorro". Além de expressar uma assimetria de gênero, esse modelo de 
casamento interétnico também empurra os índios para um tempo passado, negando sua contemporaneidade. Como McCallum, Ramos afirma que uma união inversa, isto é, o casamento de uma mulher branca com um homem indígena, é socialmente condenável e gera uma profunda reprovação moral.

Essas considerações nos ajudam a entender as reações dos brancos regionais ao casamento de Antônio e Pití. No Alto Juruá, como em outras regiões do interior da Amazônia, os índios continuam sendo objeto de discriminação e preconceitos. Considerados "não civilizados", quando não são simplesmente equiparados a animais, são alvo de uma saraivada de adjetivos depreciativos: sujo, bêbado, preguiçoso, traiçoeiro etc. Esses preconceitos produziram a identidade estigmatizada do índio como "caboclo", isto é, um índio que "se vê com os olhos do branco" (Cardoso de Oliveira 1964:80). Neste cenário interétnico de discriminação profundamente enraizada contra os povos indígenas, o casamento entre brancos e índios também é um estigma social (Goffman 1968). No entanto, em conformidade com a ideologia nacional da miscigenação, a variável gênero opera para atenuar ou reforçar fortemente esse estigma.

Assim, uniões entre homens brancos e mulheres indígenas foram frequentes no Acre, de modo geral, e no Alto Juruá, em particular, durante todo o ciclo da borracha. Estimulados pela grande carência de mulheres brancas na época, casamentos entre seringueiros nordestinos e mulheres indígenas criaram as bases sociológicas da sociedade acreana. Muitos desses casamentos, é importante nunca esquecer, foram uniões forçadas, originadas da violência colonial e do estupro de um número incalculável de mulheres indígenas. ${ }^{11}$ Enquanto esse tipo de arranjo matrimonial era social e moralmente admissível, o casamento de uma mulher branca com um homem indígena era impensável, considerado um insulto moral e uma desonra para a família da esposa. O matrimônio de uma branca com um índio não significava apenas um casamento hipogâmico, mas era visto como uma aberração, uma afronta às normas e uma ofensa à sociedade. Assim, a indignação de Nega Soares ao ver a filha casar com um "caboclo sujo e nojento", para usar seus próprios termos, não surpreende. Trata-se de uma manifestação dessa ideologia socialmente compartilhada e deve ser situada nesse contexto. Ao casar-se com Antônio, Pití quebrou as convenções sociais e morais vigentes na sua sociedade. Sofreu com a discriminação dos brancos regionais e foram anos antes que seu matrimônio fosse, pelo menos, tolerado por sua mãe e alguns familiares.

Para os Ashaninka do rio Amônia, o casamento de Antônio e Pití foi visto de modo bem distinto. Em geral, os Ashaninka também desaprovam casamentos com brancos e uniões deste tipo são pouco frequentes (Lenaerts 
2004:26). Genericamente chamado viracotxa ${ }^{12}$ o branco é marcado pela ambiguidade e ocupa um lugar de destaque na cosmologia ashaninka. Detentor dos produtos industrializados, de conhecimentos e poderes extraordinários, ele é, acima de tudo, associado às doenças, à morte e à categoria genérica de espíritos malignos ou demônios (kamari). Sua alteridade radical pode ser domesticada, mas o relacionamento com ele e, sobretudo, o intercurso sexual habitualmente apresentam um potencial perigoso. Um/a ashaninka sempre prefere casar-se com outro/a ashaninka, de preferência com primo/a cruzado/a bilateral. Como no caso dos Wari' (Vilaça 1999:256), os Ashaninka admitem casamentos ocasionais com outros povos indígenas, mas evitam uniões matrimoniais com brancos. Agindo desse modo, procuram manter as fronteiras interétnicas bem definidas. Casar-se com branco confunde esses limites. Nesse sentido, a visão que os Ashaninka do rio Amônia têm dos brancos assemelha-se muito à dos Kaxinawá do Alto Purus: "bons para trocar, eles são ruins para conviver e, especialmente, para casar" (McCallum 1997:122, tradução minha).

Embora o casamento de Antônio e Pití seja considerado pelos Ashaninka como uma união fora do comum, insólita diante dos padrões de sua sociedade, os índios dizem que Samuel Piyãko nunca se opôs a esse casamento. Ao contrário, afirmam que ele até o encorajou, quando percebeu a determinação de seu filho e os possíveis ganhos que esse matrimônio poderia trazer para o seu povo. Para muitos ashaninkas, esse casamento é visto como uma estratégia política consciente de Samuel para se aliar aos brancos regionais. Assim, os índios comentam que a aliança matrimonial foi decorrente da relação de amizade que Samuel construiu com Chico Coló, pai de Pití. Como veremos a seguir, é uma relação que os Ashaninka do rio Amônia interpretam a partir de uma reelaboração de seu sistema de trocas tradicionais chamado ayompari. Embora possa ser apenas uma reconstrução dos eventos a postiori, essa hipótese merece ser considerada com mais atenção.

\section{Um casamento estratégico: ayompari com os brancos}

A instalação de Thaumaturgo Ferreira e da família de Chico Coló no médio Amônia inaugurou um movimento migratório que aumentou nas décadas de 1970 e, sobretudo, na de 1980, com a intensificação da exploração madeireira. Durante esse período, os conflitos entre índios e brancos se multiplicaram e os Ashaninka começaram a se mobilizar politicamente para a demarcação de seu território, oficialmente reconhecido pela Funai em 1992. Samuel Piyãko, homem hábil e sagaz, parece ter antecipado esse 
movimento de chegada maciça dos brancos no território indígena e viu no casamento de seu filho com uma mulher branca regional uma oportunidade singular para neutralizar, ou pelo menos minimizar, os efeitos negativos do contato interétnico.

A relação entre casamento e política é um tema clássico da antropologia. Como revelam alguns trabalhos sobre povos indígenas das terras baixas sul-americanas, a aliança matrimonial é uma das opções disponíveis para tentar controlar as vicissitudes do contato com os não índios. No caso dos Yanomami, por exemplo, Albert (2002:244-245) relatou que o casamento do líder Davi Kopenawa com uma índia yanomami foi uma estratégia política orquestrada por seu sogro Lourival. Naquela época, Davi era chefe de posto da Funai do Demini. Ao oferecer uma de suas filhas em casamento a esse jovem yanomami, conhecedor da língua portuguesa e com relações privilegiadas com o mundo dos brancos, Lourival esperava otimizar seu acesso aos bens manufaturados, especialmente aos medicamentos ocidentais necessários para combater as epidemias que dizimavam seu grupo em decorrência do contato caótico com brancos invasores de seu território. Este caso, embora não envolva uma mulher branca, mostra como o casamento pode operar como condutor político. De forma parecida, os Ashaninka do rio Amônia afirmam que Samuel concordou com o casamento de Antônio e Pití porque viu nele uma maneira de selar uma aliança com um branco regional, a chance de controlar os efeitos negativos do contato e de ter um maior acesso aos bens manufaturados.

A etnologia das terras baixas também tem mostrado que a abertura indígena à alteridade pressupõe a possibilidade de estabelecer alianças que podem transformar os brancos em afins potenciais. Em sua síntese da teoria do parentesco na Amazônia indígena, Viveiros de Castro (2002) destacou a noção de "afinidade potencial" e a figura dos "terceiros incluídos" como mediadores fundamentais entre o interior e o exterior, a identidade e a alteridade. Para este autor, um "afim potencial" é um indivíduo com quem não se tem uma relação de afinidade real, mas uma relação genérica e coletiva, uma vez que a afinidade potencial é a condição exterior do parentesco amazônico. A "afinidade potencial" é definida como um fenômeno político-ritual, exterior e superior ao plano do parentesco, que permite mediar e qualificar as relações entre "nós" e os "outros": compatriotas e inimigos, vivos e mortos, humanos e animais, humanos e espíritos (:159).

Por sua vez, os "terceiros incluídos" são "efetuações complexas da afinidade potencial, cristalizações rituais e políticas dessa categoria tipicamente amazônica" (:154) que medeiam entre o mesmo e o outro, podendo aparecer de formas variadas geralmente associadas ao lugar simbólico 
da afinidade. Isto possibilita abrir o campo do parentesco à alteridade e socializar o exterior, escapando ao dualismo consanguíneos versus afins ou parentes versus estrangeiros, já que como afins potenciais localizam-se em posições entre a consanguinidade e a afinidade efetiva. Ao estabelecerem relações ritualizadas com indivíduos da categoria de afins potenciais, esses "terceiros incluídos" articulam o interior do campo do parentesco com o que lhe é exterior. Atuam como uma ponte entre "nós" e os "outros" e são figuras-chave nas concepções amazônicas da afinidade. Como mostrarei a seguir, a noção de "terceiros incluídos" aparece entre os Ashaninka na forma dos parceiros rituais de troca ou amigos.

Em seu trabalho na região do Alto Purus, McCallum (1997) mostrou que a palavra txai, usada por homens kaxinawá para se referirem a seus cunhados ou a primos cruzados bilaterais, se estendeu gradualmente para incluir antropólogos e ativistas de ONGs do Acre considerados "amigos dos índios". Esse dinamismo da figura do txai revela a ambivalência dos brancos e a possibilidade de alguns deles se tornarem afins potenciais. De modo semelhante ao txai dos Kaxinawá, os índios do rio Amônia possuem um termo que também pode ser aplicado a alguns brancos em contextos interétnicos específicos, como patrões, regatões, antropólogos, indigenistas etc.

Os Ashaninka interpretam as diversas relações de troca com os brancos, em diferentes períodos históricos, a partir de seu sistema de trocas tradicionais chamado ayompari. ${ }^{13}$ Provavelmente introduzida na Selva Central peruana por indígenas falantes de quíchua, a palavra ayompari parece derivar do termo espanhol "compadre" que, na língua quíchua, se converte em cumpari; este, por sua vez, se "arawakaniza" foneticamente na forma de yumparai ou yompari (Schäfer 1991:45-46; Hvalkof \& Veber 2005:228). À semelhança da palavra "ashaninka", que pode ser traduzida em português por "nós, os parentes / nós, a família", ayompari é composto pelo prefixo inclusivo da primeira pessoa do plural " $a$ " ("nós"), seguido do termo "yompari", que os Ashaninka do rio Amônia traduzem em português como "amigo" ou "parceiro de troca". Para se referir a seu yompari, um homem ashaninka recorrerá à forma inclusiva da primeira pessoa do singular e o chamará nyompari, "meu amigo" ou "meu parceiro de troca".

Os Ashaninka dizem ainda que a palavra ayompari tem diferentes significados e pode ser usada em diversos contextos. Pode expressar, por exemplo, uma forma de interação social amistosa entre indivíduos ashaninkas que não se conhecem ou não têm laços de parentesco. Embora todos os Ashaninka se considerem, de certa forma, "parentes", como expressado no próprio etnônimo, a esfera do parentesco efetivo entre dois indivíduos é limitada por suas relações reais de consanguinidade e afinidade. Assim, os 
índios do Amônia afirmam que o termo ayompari pode ser utilizado para se referir a esses "outros ashaninkas", por exemplo, membros de outras comunidades, com os quais não têm laços efetivos de parentesco, mas que são potencialmente "amigos". Nesse contexto, entre indivíduos ashaninkas, o ayompari apresenta a figura de um "outro semelhante". Num sentido mais restrito, ayompari também designa uma relação formalizada de amizade e troca entre dois ashaninkas que decidem "fazer ayompari", ou seja, tornar-se verdadeiros amigos e parceiros de troca.

O sistema de trocas ayompari já foi tema de reflexão de alguns etnólogos que trabalharam com os Ashaninka. A partir de suas pesquisas no Gran Pajonal, no rio Pichis e no alto Ucayali, iniciadas na década de 1960, Bodley (1973) foi o primeiro a definir o sistema tradicional de intercâmbio desse povo indígena como troca deferida. O ayompari foi também objeto de reflexões de Shäfer (1991) e, mais recentemente, de Hvalkof e Veber (2005:226-235), e Killick (2008). Em publicações anteriores, também procurei mostrar como o ayompari é atualizado pelos Ashaninka do rio Amônia para qualificar suas novas formas de parceria com os brancos no contexto do indigenismo amazônico contemporâneo (Pimenta 2006, 2009). Aqui, quero apenas apontar algumas de suas principais características para mostrar como os índios usam a relação ayompari para explicar o casamento de Antônio e Pití.

De modo geral, a instituição ayompari permite a um indivíduo estabelecer, através da troca, relações de amizade e parceria com outro indivíduo, ashaninka ou não, situado fora do domínio do parentesco. A troca de bens entre parceiros é um aspecto importante da relação ayompari. Como no Gran Pajonal (Shäfer 1991), os Ashaninka do rio Amônia definem o ayompari como um "amigo que me dá coisas". Qualquer ashaninka adulto pode ter um ou vários parceiros de troca, número que varia em função do interesse e do prestígio dos indivíduos envolvidos na relação, todavia é limitado. Segundo Shäfer (:61), os Ashaninka do Gran Pajonal têm, em média, de três a cinco parceiros de troca, mas alguns líderes podem ter mais de dez ayompari, preferencialmente outros líderes em territórios próximos e distantes. No rio Amônia, os índios estimam que três ou quatro ayompari é um número razoável. Consideram que um único parceiro limita a troca e um número exagerado pode pôr em risco a relação, pela impossibilidade de cumprir a exigência de reciprocidade.

Uma relação ayompari não se limita à sua dimensão econômica. A instituição obedece à regra moral da tríplice obrigação maussiana de "dar, receber e retribuir", na qual o prestígio e a honra são dimensões fundamentais. Confiança, generosidade, lealdade e honestidade são virtudes essenciais de um ayompari. Shäfer (1991) teve o mérito de enfatizar os 
aspectos sociais, culturais e emocionais dessa instituição. Definido inicialmente como um sistema de trocas ritualizadas e internas aos Ashaninka, o ayompari é reinterpretado em função das contingências para incluir outros povos indígenas e também brancos. Assim, os índios do rio Amônia afirmam que seus antepassados já "faziam ayompari" com outros índios na Selva Central peruana antes de conhecerem os brancos. ${ }^{14}$ Após a conquista, as cobiçadas mercadorias ocidentais intensificaram o comércio interétnico e expandiram as fronteiras do ayompari para a alteridade, incorporando os brancos. Ou seja, em diversas situações históricas, os Ashaninka apreendem suas relações com os não índios a partir de seu sistema de trocas tradicional, criando dessa forma uma espécie de "ayompari interétnico".

Ao discutir a aquisição, a distribuição e o consumo de bens manufaturados entre os Barasana e outros tukanos do rio Pirá-Paraná da região colombiana do Vaupés, Hugh-Jones (1992) mostrou que as lógicas que informam as economias indígenas diferem da racionalidade ocidental, mas há também a possibilidade de articulação dos sistemas nativos com as economias dos brancos, como no caso do aviamento. No início da década de 1970, Bodley (1973:595) já apontava a proximidade entre o ayompari ashaninka e o sistema do aviamento, conhecido no Peru como habilitación, mostrando que o termo nativo para parceiro de troca e amigo também podia ser traduzido por "patrão". Esta mesma ideia foi retomada por Killick (2008), que mostrou que os pequenos patrões mestiços se tornaram os ayompari privilegiados dos Ashaninka do Ucayali, cada grupo entendendo sua inserção no sistema madeireiro a partir de seu código cultural específico, levando a diferentes compreensões da relação social e da situação interétnica. Enquanto os Ashaninka usam a linguagem do ayompari para fazer sentido nas relações com os patrões, estes últimos interpretam sua relação com os índios como compadrio (compadrazgo). Como Bodley (1973), Killick (2008:314) afirma ainda que ambos os sistemas, apesar de diferenças importantes, enfatizam os laços sociais e que o termo espanhol patrón é geralmente usado pelos índios como sinônimo de amigo ou ayompari.

Essas considerações sobre o ayompari e sua dinâmica na literatura etnográfica ajudam-nos a entender como os Ashaninka do rio Amônia perceberam o casamento de Antônio e Pití. A relação ayompari não é uma pré-condição para a aliança matrimonial interétnica mas, como o txai dos Kaxinawá, o ayompari ashaninka é um exemplo desses "terceiros incluídos" que permitem a abertura do grupo local para a alteridade e a articulação do interior com o exterior. Assim, como parceiro ritual e amigo, o ayompari apresenta-se como um afim potencial por excelência. Embora pouco frequente, os Ashaninka afirmam que é possível a dois ayompari, além 
de trocarem bens materiais, também trocarem suas filhas em casamento, transformando o "afim potencial" em afim efetivo. Os Ashaninka dizem que Samuel não considerava o pai de Pití como patrão. No entanto, como vimos, os dois homens se tratavam em português como compadres. Apesar de Chico Coló não ser visto como patrão, os índios dizem que ele e Samuel trocavam bens e serviços e que a relação de amizade que os unia era uma forma de ayompari, também baseada no respeito mútuo e nos valores morais que essa relação pressupõe.

\section{Os efeitos políticos}

O casamento de Antônio e Pití não só inverteu a prática dos matrimônios regionais, como também mudou profundamente a história dos Ashaninka do rio Amônia. Quando ocorrem, as alianças interétnicas unem geralmente mulheres indígenas e homens brancos, e os casais passam a residir nas cidades ou junto à família do marido branco e não na comunidade indígena. É o que acontece no alto rio Negro, por exemplo, nos casamentos interétnicos analisados por Lasmar $(2005: 197-212,2008)$, na cidade de São Gabriel da Cachoeira. No alto Purus, encontramos esse mesmo padrão. Assim, como mostrou McCallum (1997:126), a mulher kaxinawá que casa com um branco deixa sua família para morar com o marido, próximo ao sogro ou num novo local, num padrão de residência patrilocal ou neolocal. Em caso de separação, ela volta para sua aldeia de origem com os filhos, que passam a ser criados como índios, enquanto o pai branco simplesmente desaparece de seu convívio social. Muito menos frequentes, as uniões entre mulheres brancas e homens indígenas seguem esse mesmo padrão de residência pós-marital patrilocal ou neolocal. Em sua pesquisa em São Gabriel da Cachoeira, Lasmar (2005:200-201) também afirma que os raros casamentos entre mulheres brancas e homens indígenas eram, "na maioria dos casos, de homens envolvidos de longa data com o movimento indígena e com larga experiência de relação com os brancos" (:201). No caso aqui analisado, nos deparamos com uma situação muito distinta. A experiência de Antônio com os brancos limitava-se, basicamente, às relações com os patrões e com a família de Chico Coló. Além disso, embora ele tenha morado um curto período junto a seu sogro, foi Pití que passou a viver entre os Ashaninka do rio Amônia, indo assim não só contra o modelo regional, mas também contra o padrão de residência ashaninka que favorece a uxorilocalidade (Varese 2002:18; Hvalkof \& Veber 2005: 162). Reside, aí, mais uma peculiaridade desse casamento. 
É difícil pensar que o casamento de Pití e Antônio seja um caso isolado. No entanto, é certamente atípico. Segundo meus interlocutores, é o único de que se tem notícia na região do Alto Juruá e desconheço situação semelhante na literatura etnográfica. Assim, esse casamento é um caso raro de uma esposa branca que se tornou parte da vida de uma sociedade indígena, na qual passou a ocupar uma posição de destaque, mas também ambígua.

Em meados da década de 1980, no auge da exploração madeireira, Pití foi uma barreira à escravização dos índios, revoltando-se contra todas as formas de arbitrariedade e discriminação. Ela desempenhou um papel fundamental na mediação dos conflitos interétnicos no rio Amônia e chegou a se opor a membros de sua própria família que trabalhavam como mão de obra para os patrões madeireiros e ocupavam o território ashaninka. Mulher corajosa e discreta, animada por um intenso sentimento de justiça, nunca duvidou da legitimidade das reivindicações indígenas e apoiou constantemente a luta dos Ashaninka pelos seus direitos, procurando sempre apaziguar os conflitos interétnicos e buscar soluções pacíficas. Mediadora incansável, foi peça-chave para persuadir membros de sua família de origem da necessidade de deixar o território indígena. Sem nunca tomar a frente da cena política, trabalhou muito nos bastidores, aconselhando e orientando seu sogro, seu marido e seus filhos mais velhos sobre a melhor atitude a adotar nas relações com a Funai e com os brancos da região. Além de conselheira, passou também a atuar como parteira e enfermeira, dentre várias outras funções informais que exerce na comunidade indígena.

A posição ocupada por Pití entre os Ashaninka do rio Amônia é bastante ambígua e peculiar. Ela entrou na esfera do parentesco sem abandonar sua identidade de branca. Com o passar dos anos, mergulhou na cultura ashaninka e conquistou gradualmente a confiança e o respeito dos índios com suas atitudes e ações. Com mais de meio século de convivência diária, entende perfeitamente a língua ashaninka, mas se expressa quase exclusivamente em português. Aprendeu a tecer algodão com Mariwãtxo, mãe de Antônio, mas não veste a kushma, utilizada cotidianamente por todas as mulheres indígenas da aldeia. Embora os índios se refiram a ela usando termos de parentesco, nunca deixaram de considerá-la como uma mulher branca, marcando, assim, sua posição peculiar no seio da comunidade. Mesmo participando do cotidiano da vida ashaninka, Pití jamais abdicou de sua identidade branca e está totalmente consciente de sua diferença. Ela não "virou Ashaninka", assim como Antônio nunca "virou branco". ${ }^{15}$

Pití possibilitou ao marido aprimorar o seu conhecimento da sociedade dominante e teve um papel decisivo na educação de seus sete filhos. Todos reconhecem sua importância, têm-lhe um profundo respeito e uma 
admiração absoluta. Como mostrei em outras ocasiões, o domínio da língua portuguesa e a compreensão do mundo dos brancos foram elementos significativos, embora não únicos, para a afirmação de Antônio Pyãko como "chefe" ou curaca dos Ashaninka do rio Amônia na década de 1980, após a morte de Samuel (Pimenta 2015c, 2017). Na aldeia Apiwtxa, graças ao casamento com Pití, Antônio adquiriu uma posição estrutural muito especial durante a luta pela terra. Pití possibilitou seu acesso privilegiado à sociedade regional e tornou suas relações com os brancos mais eficientes, permitindo a Antônio abastecer os Ashaninka com mercadorias, um fator importante que lhe rendeu aumento de prestígio e a lenta construção de sua legitimidade política entre os índios. O mesmo pode ser dito do surgimento e da consolidação, nos últimos vinte anos, dos filhos e filhas de Antônio e Pití, como novos e, até hoje, praticamente únicos líderes dos Ashaninka do rio Amônia.

Como muitos novos líderes indígenas, os filhos de Antônio e Pití são o resultado dessa mistura. Nascidos de um casamento interétnico, viveram a ambivalência de pertencer a dois mundos muito diferentes: a sociedade dos brancos representada pela família materna e o mundo ashaninka do lado paterno. Souberam trabalhar essa peculiaridade a seu favor e a favor de sua comunidade. Socializados entre os Ashaninka, eles nunca deixaram de ter contato com seus parentes maternos, que sempre moraram nos arredores. Alfabetizados pela mãe, também tiveram uma educação escolar mínima, mas privilegiada, se comparada aos outros ashaninkas do rio Amônia. Tornaram-se fluentes em português. Aprenderam a escrever, ler e contar. Mostram qualidades distintas, mas complementares, que também lembram muitos valores importantes da sociedade indígena, tais como: generosidade, coragem, oratória etc.

Embora os Ashaninka não valorizem o "sangue misturado", como fazem os Piro do Baixo Urubamba (Gow 1991), esses novos líderes desfrutam de muito prestígio entre os índios do rio Amônia. Informados pelo modo de ser branco, passaram a afirmar com orgulho sua identidade ashaninka. No rio Amônia, como em outras regiões da Amazônia (ver, por exemplo, Veber \& Virtanen 2017), as formas indígenas de liderança mudaram profundamente nas últimas décadas com a intensificação do contato interétnico e a influência de novos atores do indigenismo (ONGs etc.). No Amônia, uma educação bilíngue e o conhecimento do mundo dos brancos foram fatores essenciais para a ascensão e a afirmação política desses novos líderes.

A política interétnica dos Ashaninka do Amônia é hoje articulada por esses filhos e filhas de Antônio e Pití. Eles dirigem a associação da terra indígena, assim como a organização e a gestão da cooperativa. Alguns 
exercem também funções de destaque na comunidade, como professores, agentes de saúde e agentes agroflorestais. A visibilidade política dos Ashaninka do rio Amônia, construída nos últimos vinte anos no campo de indigenismo e do ambientalismo amazônico, se deve essencialmente ao carisma e à habilidade desses novos representantes para negociar com seus diversos parceiros não indígenas.

Por si só, o casamento de Antônio e Pití não é suficiente para explicar toda a história recente dos Ashaninka do rio Amônia e a configuração atual dessa sociedade. Como mostrei alhures (Pimenta 2015c, 2017), a organização social e a política contemporânea desse coletivo se devem a diversos fatores internos e externos. Resultam de um processo complexo que só pode ser compreendido se levamos em consideração as estruturas e os valores da sociedade ashaninka e as especificidades da conjuntura histórica local, ou "a estrutura da conjuntura", para usar a expressão de Sahlins (1981). Embora não desvende todas as facetas dessa história, o casamento de Antônio e Pití é um evento central para explicar o protagonismo atual dos Ashaninka do rio Amônia no campo interétnico.

\section{Epilogo}

Tomando como foco principal a análise do casamento de Antônio e Pití e recuperando a trajetória de suas famílias, este artigo também procurou revisitar a história do Alto Juruá e, principalmente, do rio Amônia, questionando algumas premissas precipitadas sobre a ocupação da região. Assim, a história oral dos Ashaninka revela que eles já utilizavam o curso médio e alto do rio Amônia antes de esse território tornar-se brasileiro e que nunca foram joguetes passivos nas mãos dos patrões regionais. Trazer à tona a agência indígena na abordagem da história não é uma questão de opção teórica, mas de fidelidade aos dados etnográficos e de lealdade ao modo ashaninka de se situar no mundo. De forma semelhante, é fundamental salientar a atitude, a coragem e a força extraordinária de Pití que é, sem dúvida, personagem central nessa história. Seu protagonismo começou com a ousadia de se casar com um "caboclo", desafiando as convenções sociais e a moral preconceituosa de seus compatriotas.

O principal objetivo deste trabalho foi destacar o valor sociológico e político de um casamento atípico que sempre despertou muita curiosidade nos visitantes brancos que passam pela aldeia Apiwtxa e se revelou muito fecundo para a análise antropológica. Sua importância e singularidade esclarecem, com o olhar apropriado, a situação peculiar ocupada pelos 
Ashaninka do rio Amônia no contexto etnográfico regional. Porém, apresentar o casamento de Antônio e Pití como uma "estratégia política" de Samuel Pyãko não deve deixar em segundo plano uma dimensão crucial que envolve toda essa relação, ou seja, os sentimentos que unem o casal há mais de meio século. Essa dimensão sentimental expressa-se de modo muito sutil na troca de olhares, nos cuidados do dia a dia, mas nunca na esfera pública. O pudor extremo dos Ashaninka do rio Amônia, que é também o de Pití, em relação a qualquer demonstração de afetividade amorosa no espaço público chega a ser desconcertante para alguém pouco familiarizado com o modo de ser nativo. Embora sejam extremamente divertidos, com um humor muito sarcástico, os Ashaninka demonstram uma capacidade impressionante de controlar certas emoções e manter uma postura corporal imperturbável. É como se, na presença de terceiros, eles manifestassem uma extraordinária impassividade diante de qualquer forma de expressão de sentimentos amorosos que possa expô-los de alguma maneira a uma situação de fragilidade.

Os Ashaninka do rio Amônia dizem não ter um termo específico para traduzir a palavra "amor". Para expressar este sentimento, usam o termo nasakãne, "meu coração", e traduzem a expressão "eu te amo" por nasãkanetakine, literalmente "você é meu coração". Falar de amor em público ou simplesmente para um interlocutor, mesmo familiar, é pouco frequente, a menos que seja num tom jocoso. Como um guerreiro que não deve demonstrar medo, também não se deve expor o amor em público. Evita-se falar abertamente de sentimentos amorosos, ou se fala o estritamente necessário e de modo muito alusivo. Demonstrar amor com gestos de carinho em público é uma atitude extremamente desrespeitosa e até inimaginável, fonte de um profundo mal-estar. Assim, tanto Pití como Antônio, quando convidados a falar sobre o próprio namoro, sobre os sentimentos que nutrem um pelo outro, sempre foram muito comedidos. Manifestavam um tal incômodo e constrangimento que impunham limites à pesquisa etnográfica. Em suma, tudo se resumia à afirmação genérica e pouco expressiva: "a gente se gostou". Tantas vezes repetida, esta resposta trazia um recado indireto, polido, mas firme, para frear a curiosidade do etnógrafo. ${ }^{16}$

O tema do amor é, de fato, muito instigante no universo ashaninka e mereceria uma investigação mais profunda. Esse povo indígena parece ter um modo muito peculiar de (não) expressar seus sentimentos amorosos. Ao mesmo tempo em que procuram controlar sua manifestação em público, principalmente gestual, o amor está sempre presente em vários aspectos da vida social e na filosofia ashaninka. Ele se revela, por exemplo, na importância dada à sedução e à beleza. Aparece também nas frequentes piadas com conotação sexual ou na arte, em especial, nas músicas, nos cuidados com 
as roupas, com os adereços, no uso de pinturas, perfumes e na preparação de substâncias caseiras com propriedades mágicas (posãka) para atrair o sexo oposto. ${ }^{17}$ Diante disso, é necessário esclarecer que o título dado a este artigo, "amor rebelde", tem sobretudo um efeito retórico e não pretende expressar nem o sentimento ashaninka, nem o dos principais protagonistas. Como procurei esclarecer, se esse matrimônio foi rebelde ou, pelo menos, ousado e desafiador, foi de fato para a sociedade branca regional.

Desde o casamento, distantes dos holofotes que iluminam as atividades de alguns de seus filhos, que se tornaram personagens conhecidos do indigenismo e do ambientalismo nacional e até internacional, Pití e Antônio sempre levaram uma vida pacata, mesmo sendo a âncora da vida social e política dos Ashaninka do rio Amônia. Em janeiro de 2000, quando cheguei pela primeira vez a Marechal Thaumaturgo e pedi informações sobre aquela comunidade, muitos interlocutores responderam fazendo referência não aos Ashaninka ou aos "Kampa", mas aos "índios da Pití", expressando assim a centralidade desta mulher branca na vida deles. A casa de Pití e Antônio tornou-se a principal referência da aldeia Apiwtxa, recebendo visitas constantes dos Ashaninka e dos brancos de passagem. Os índios dizem, com freqüência, que "a vida na comunidade acaba" quando Pití e Antônio saem por dias ou semanas para alguma tarefa em Marechal Thaumaturgo ou Cruzeiro do Sul. Essa sensação deixa-os com a impressão de que o cotidiano se torna moroso e que o tempo custa a passar. Sem a presença do casal, o sentimento geral é de que a vida na comunidade fica tristonha. Sem Antônio e Pití a história dos Ashaninka do rio Amônia seria, sem dúvida, muito diferente.

Constrói-se, agora, um novo capítulo da história dos Ashaninka e do Alto Juruá. Isaac, neto de um ashaninka peruano e de um amazonense, filho de um "caboclo sujo e fedorento" e de uma audaciosa mulher branca regional, desafiou todos os prognósticos e foi eleito para a Prefeitura do município de Marechal Thaumaturgo, em outubro de 2016, tornando-se o primeiro prefeito indígena na história do Acre. Acompanhado dos pais e irmãos, tomou posse vestindo a kushma e fez um discurso comovente no qual lembrou a trajetória do seu povo e de sua família. A façanha de Isaac, num município onde o preconceito contra os povos indígenas ainda é extremamente forte, brinda-nos com a esperança de um futuro mais confiante e mais tolerante para com os Ashaninka e os outros povos indígenas da região. Por fim, além de um artigo acadêmico, este texto é sobretudo uma singela e humilde homenagem a um casal extraordinário, que me acolheu em sua residência durante um ano de trabalho de campo e que continua me recebendo, periodicamente, com muito afeto. 


\section{Agradecimentos}

Agradeço a Alcida Rita Ramos, Wilson Trajano Filho, Andrea de Souza Lobo, Luís Cayón e Alexandrina Pinhanta (Shãtsi) pelos preciosos comentários a uma versão preliminar deste artigo. Agradeço também os pareceristas anônimos pelas sugestões.

Recebido em 28 de agosto de 2017

Aprovado em 30 de junho de 2018

José Pimenta é doutor em Antropologia pela Universidade de Brasília (2002) e professor associado do Departamento de Antropologia da mesma Universidade. Desenvolve pesquisas com os Ashaninka do rio Amônia (Alto Juruá - Acre) desde 1998, tendo como foco de interesse principal as seguintes áreas e temas: etnologia indígena, indigenismo, política, desenvolvimento, sustentabilidade e fronteira. E-mail: josepimenta17@gmail.com 


\section{Notas}

1 Os Ashaninka, Asheninka e outros Arawak subandinos (Matsiguenga, Nomatsiguenga e Yanesha) foram durante muito tempo chamados de Campa (ou Kampa, no Brasil), uma denominação externa que nada significa para eles e que é vista como pejorativa. Assim, em 1992, o território indígena dos Ashaninka do rio Amônia foi erroneamente demarcado como Terra Indígena Kampa do rio Amônia. A grande maioria da população indígena desse território é, na realidade, Asheninka e não Ashaninka. Embora existam diferenças linguísticas e culturais bastante relevantes entre os dois grupos, essas diferenças não são muito salientes no rio Amônia, principalmente no contexto interétnico em que todos se declaram Ashaninka e são reconhecidos como tal. Por esta razão, usarei aqui o etnônimo Ashaninka para me referir tanto aos Ashaninka, como aos Asheninka.

2 O rio Juruá nasce no Peru e desagua no rio Solimões, já no estado do Amazonas. Como é de praxe na literatura sobre a região, entendo por Alto Juruá a bacia hidrográfica do rio Juruá situada acima da cidade de Cruzeiro do Sul. As cifras populacionais apresentadas para os Ashaninka estão na Base de datos de Pueblos indígenas u Originarios do Ministerio de Cultura, no caso do Peru (http://bdpi.cultura. gob.pe). Para o Brasil, foram usados os dados do Sistema de Informação da Atenção à Saúde Indígena da Secretaria Especial de Saúde Indígena (Siasi/Sesai), que podem ser consultados em: www.saude.gov.br/sesai

3 Para evitar confusões e atendendo a uma necessidade de padronização, usarei aqui somente o sobrenome Piyãko para me referir aos membros dessa família, que é o principal grupo familiar dos Ashaninka do rio Amônia. Este sobrenome tem sido grafado e registrado em cartórios de maneiras diferentes: Piyãko, Pianko ou, ainda, Pinhanta.

4 Dado obtido no página do Instituto Socioambiental: https://pib.socioambiental. org/pt/Povo:Parakanã

5 Utilizo o termo "patrão" seguindo seu uso local, ou seja, sobretudo como expressão de uma relação hierárquica, real ou imaginada entre sujeitos. No sistema do aviamento, por exemplo, o termo "patrão" é polissêmico e está muito distante da imagem simplista de um patrão reinando sozinho no seu seringal no meio da floresta, mantendo um poder implacável sobre "seus" seringueiros. Na realidade, os grandes patrões viviam geralmente distantes dos seringais e mantinham sua atuação local por meio de empregados ou "aviados", também chamados de "patrão". Um grande seringal era dividido em seringais menores, cada qual com seu patrão. Existia assim um sistema hierárquico complexo que ligava os seringueiros às casas aviadoras de Manaus e Belém e era intermediado por pequenos, médios e grandes patrões da borracha (Almeida 1993). De modo mais geral, no Alto Juruá, como em outras regiões do interior da Amazônia, é comum trabalhadores humildes usarem o termo "patrão" para qualificar um indivíduo considerado de uma posição hierárquica superior. Para os Ashaninka, como veremos adiante, o termo "patrão" também pode se referir a um "amigo" ou "parceiro de troca". 
6 As noções de "baixo", "médio" e "alto" para se referir ao curso do rio Amônia têm um caráter arbitrário. Usarei aqui o termo "baixo" para me referir à parte do rio Amônia que vai de sua foz, no rio Juruá e onde se situa a sede do atual município de Marechal Thaumaturgo, até a Terra Indígena Kampa do Rio Amônia. Entendo como "médio" Amônia toda a extensão ocupada por esse território indígena até a fronteira internacional. Considero "alto" Amônia todo o curso do rio situado em território peruano.

7 Os Ashaninka, como outros arawaks subandinos, usam uma vestimenta de algodão conhecida como kushma e chamada na língua nativa de kitharentsi. A vestimenta é um poderoso símbolo identitário e, muitas vezes, usada para se contrastar a outros índios. Assim, os Ashaninka se orgulham de nunca ter "andados nus", contrariamente aos outros povos indígenas, que só passaram a usar roupas para cobrir seus corpos com a chegada dos brancos.

8 O artigo 231 da Constituição de 1988 conceitua as terras indígenas como aquelas tradicionalmente ocupadas pelos povos indígenas. A noção de "tradição" refere-se ao modo de ocupação e de produção e não a qualquer noção de anterioridade temporal ou ocupação imemorial, ou seja, pouco importa se os Ashaninka foram ou não os primeiros a ocupar o rio Amônia. Em hipótese alguma este fato é relevante para questionar seus direitos territoriais.

9 Para simplificar, no decorrer do texto, usarei geralmente a denominação Vila Thaumaturgo para me referir à sede do atual município Marechal Thaumaturgo. Embora não seja sempre administrativamente fidedigno, é assim que esse pequeno núcleo urbano continua sendo chamado pela população local ou, mais simplesmente, como "vila".

10 Longos colares masculinos feitos de diversos tipos de sementes, usados à bandoleira em várias voltas.

11 Os nordestinos que fugiam da seca e da miséria para o Alto Juruá eram essencialmente homens que vinham para fazer uma poupança com a ideia de voltar a seus lugares de origem. Muitos acabaram ficando por vontade própria ou pela impossibilidade de saldar as dívidas contraídas com os patrões. Poucas mulheres acompanharam seus maridos ou companheiros. Como mostrou Wolff (1999), a partir de dados do coronel Thaumaturgo de Azevedo, primeiro prefeito do departamento do Alto Juruá, na época da implementação do Território Federal do Acre, em 1904, as mulheres representavam, aproximadamente, 25\% da população não indígena da região. Esse desequilíbrio, no entanto, não significa que as mulheres não tenham tido um papel importante nos seringais e não só na economia doméstica. Wolff (1999) teve o mérito de dar visibilidade a essas mulheres que foram, durante muito tempo, ocultadas pela historiografia. Nesse contexto, as mulheres indígenas, principalmente jovens, trazidas das aldeias contra a sua vontade em decorrência das correrias, eram um bem extremamente precioso. Capturadas, elas acabaram integrando a vida do seringal e constituíram família com seus algozes que também aprenderam com elas diversas técnicas indígenas de caça e pesca, o uso de diferentes espécies vegetais etc. Uma história famosa de correria, caracterizada pela captura de uma índia e o seu casamento posterior com um seringueiro branco, está na origem do povo Kontanawá (Pantoja 2008). 
12 Virakotxa é um termo de origem quéchua. Segundo Brown e Fernández (1991:142-143, nota 7), ele seria o Deus Criador Inca. Sobre o branco na cosmologia e na história ashaninka, ver, por exemplo, Pimenta (2015b).

13 Neste trabalho, opto pela grafia ayompari e não ayõpari como ela é geralmente usada pelos Ashaninka do rio Amônia. Esta opção se deve ao desejo de homogeneizar as diferentes grafias que podem ser encontradas, tanto na literatura etnográfica como nos documentos produzidos pelos indígenas: ayompari, ayompare, ayõpare, ayõpari, ayómpari etc. Essas diferentes grafias continuam a ser usadas pelos Ashaninka do rio Amônia, embora a forma ayõpari tenda a se cristalizar ultimamente. Em 2003, a cooperativa dos Ashaninka do rio Amônia foi formalizada e registrada com o nome "Ayõpare". No entanto, segundo os professores indígenas, esse registro se deve a um erro de grafia, sendo ayõpari o termo correto.

14 As relações de troca entre os Ashaninka e os outros povos indígenas da Selva Central peruana, outros Arawaks subandinos e Panos ribeirinhos, antes e depois da chegada dos espanhóis, apresentavam características do sistema ayompari. Embora não se refira explicitamente a este termo, Renard-Casevitz (1993) mostra que as expedições comerciais entre índios amazônicos também se estendiam, em tempo de paz, às populações andinas vizinhas, podendo levar ao estabelecimento de estreitas relações pessoais entre parceiros de troca que também se tornavam amigos.

15 Não pretendo discutir, aqui, as teorias do "virar branco" que têm sido usadas para explicar os processos de mudança em alguns povos indígenas da Amazônia, como os Wari' (Vilaça 1999) e os Yanomami (Kelly 2005), pois o matrimônio interétnico de Antônio e Pití não me parece exemplificar esse fenômeno. Contrariamente aos Ashaninka do Ucayali (Sarmiento Barletti 2011:84-85), os meus interlocutores do rio Amônia não afirmam que estão "virando civilizados" e, ainda menos, "virando brancos", mesmo vivendo hoje em "comunidade" e usando "coisas de branco". Ao contrário, muitos depoimentos afirmam que eles "sempre foram civilizados" e o fato de nunca terem "andado nus", em contraste com outros índios, é a principal marca de sua longa "civilização".

16 Pessoalmente nunca vi, por exemplo, um beijo em público, nem sequer um casal de mãos dadas, fosse jovem ou não. Pití e Antônio têm uma televisão em sua residência, alimentada por um motor a gasolina. O aparelho é ligado ocasionalmente, em especial para assistir à novela noturna da Globo, uma paixão da dona da casa. A televisão sempre atrai alguns ashaninkas da vizinhança, na grande maioria, mulheres e crianças. As cenas de romance das novelas, envolvendo beijos, carícias e até corpos desnudos, geram sempre um silêncio embaraçoso, quase aflitivo. A reprovação nunca era explícita, mas a indignação era geral. Os Ashaninka não entendem como os brancos podem expor seus sentimentos de maneira tão desavergonhada. Os únicos momentos em que essa atitude corporal e o controle das emoções se afrouxam um pouco é durante os rituais da caiçuma, ou pyarentsi na língua nativa.

17 Sobre a arte dos Ashaninka e a importância dada à beleza e à sedução, ver Beysen (2008). 


\section{Referências bibliográficas}

ALBERT, Bruce. 2002. "O ouro canibal e queda do céu: uma crítica xamânica da economia política da natureza". In: B. Albert \& A. Ramos (orgs.), Pacificando o branco. Cosmologias do contato no norte-amazônico. São Paulo: Editora Unesp. pp. 239-270.

ALMEIDA, Mauro. 1993. Rubber Tappers of the Upper Jurua River, Brazil. The making of a Forest Peasant Economy. Doctoral Thesis, University of Cambridge.

BALÉE. Wiliam. 1994. Footprints of the Forest: Ka'apor Ethnobotany - The historical Ecology of Plant Utilization by an Amazonian People. New York: Columbia University Press.

BEYSEN, Peter. 2008. Kitarentse. Pessoa, arte e estilo de vida ashaninka do oeste amazônico. Tese de Doutorado em Antropologia, Universidade Federal do Rio de Janeiro.

BODLEY, John. 1973. "Deferred Exchange among the Campa Indians". Antropos, 68:589-596.

BROWN, Michael \& FERNÁNDEZ, Eduardo. 1991. War of Shadows: the Struggle for Utopia in the Peruvian Amazon. Berkeley: University of California Press.

CARDOSO DE OLIVEIRA, Roberto. 1964. O índio e o mundo dos brancos. São Paulo: Difusão Europeia do Livro.

CARNEIRO DA CUNHA, Manuela. 2009. "Cultura com aspas". In: Cultura com aspas. São Paulo: Cosac e Naify. pp. 311-373.

FAUSTO, Carlos. 2001. Inimigos fiéis: história, guerra e xamanismo na Amazônia. São Paulo: Edusp.

GOFFMAN, Erving. 1968. Stigma: Notes on the Management of Spoiled Identity. New York: Pelican.

GOW, Peter. 1991. Of Mixed Blood.
Kinship and History in Peruvian Amazon. Oxford: Oxford University Press.

HUGH-JONES, Stephen. 1992 . "Yesterday's luxuries, tomorrow's necessities: business and barter in Northwest Amazonia". In: C. Humphrey e S. Hugh-Jones (orgs.), Barter, exchange and value: an anthropological approach. Cambridge: Cambridge University Press. pp. 42-74.

HVALKOF, Søren \& VEBER, Hanne. 2005. "Los Ashéninka del Gran Pajonal". In: F. Santos Granero \& F. Barclay (orgs.), Guía Etnográfica de la Alta Amazonía, volume V, Campa Ribereños, Ashéninka. Lima: Instituto Smithsonian de Investigaciones Tropicales / Instituto Francês de Estudios Andinos. pp. 75-279.

IGLESIAS, Marcelo. 2010. Os Kaxinawá de Felizardo: correrias, trabalho e civilização no Alto Juruá. Brasília: Paralelo 15.

KELLY, José. 2005. "Notas para uma teoria do "virar branco'". Mana, 11 (1):201-234

KILLICK, Evan. 2008. "Godparents and Trading Partners: Social and Economic Relation in Peruvian Amazon". Journal of Latin American and Caribbean Studies, 40:303-328.

LASMAR, Cristiane. 2008. "Irmã de índio, mulher de branco: perspectivas femininas no Alto Rio Negro". Mana, 14 (2):429-454.

2005. De volta ao Lago de Leite. Gênero e transformação no Alto Rio Negro. Rio de Janeiro: Unesp-ISA.

LENAERTS, Marc. 2004. Anthropologie des indiens Ashéninka d'Amazonie. Nos soeurs Manioc et l'étranger Jaguar. Paris: L'Harmattan.

McCALLUM, Cecilia. 2001. Gender and Sociality in Amazonia. How Real People are Made. New York/Oxford: Berg. 
1997. "Eating with Txai, eating like Txai". Revista de Antropologia, 40 (1):109-147.

PANTOJA, Mariana. 2008. Os Milton. Cem anos de história nos seringais. Rio Branco: Edufac.

PERRISSER, Jean-Baptiste. 2009 [1898]. "Seis meses no país da borracha, ou excursão apostólica ao rio Juruá, 1898". In: M. Carneiro da Cunha (org.), Tastevin, Perrissier. Fontes sobre índios e seringueiros no Alto Juruá. Rio de Janeiro: Museu do Índio/Funai. pp. 1-60.

PIMENTA, José. 2017. 'AAll together': Leadership and community among the Ashaninka (Brazilian Amazon)". In: H. Veber \& P. Virtanen (eds.), Creating Dialogues: Indigenous Perceptions and Forms of Leadership in Amazonia. Boulder: University Press of Colorado. pp. 169-198.

. 2015a. "O amazonismo acriano e os povos indígenas: revisitando a história do Acre". Amazônica: Revista de Antropologia, 7 (2):327-353.

. 2015b. "'Alteridade contextualizada': variações ashaninkas sobre o branco". Anuário Antropológico, 40 (1):281-309.

2015c. "Du 'temps des patrons' au 'temps des droits': Conflits interethniques et transformations politiques chez les Ashaninka d'Amazonie brésilienne". Journal de la Société des Américanistes, 101 (1):269-294.

2009. "Parceiros de Troca, Parceiros de Projetos. O ayompari e suas variações entre os Ashaninka do Alto Juruá". M. I. Smiljanic; J. Pimenta \& S. Baines (orgs.), Faces da Indianidade Smiljanic. Nexus: Curitiba. pp. 101-126.

2006. "De l'échange traditionnel à l'économie du 'développement durable'. La notion de 'projet' entre les Ashaninka du Haut-Juruá (Ama- zonie brésilienne)". Cahiers du Brésil Contemporain, 63/64:17-50.

RAMOS, Alcida. 1998. Indigenism. Ethnic Politics in Brazil. Madison: University of Wisconsin Press.

RENARD-CASEVITZ, France-Marie. 1993. "Guerriers du sel, saumiers de la paix". L'Homme, 126-128:25-43.

RIVAL, Laura. 2002. Trekking through History: the Huaorani of Amazonian Ecuador. New York: Columbia University Press.

SAHLINS, Marshall. 1981. Historical Metaphors and Mythical Realities. Structure in the Early History of the Sandwich Islands Kingdow. Ann Arbor: The University of Michigan Press.

SARMIENTO BARLETTI, Juan Pablo. 2011. Kametsa Asaiki: The pursuit of 'Good life' in an Ashaninka Village. PhD. Thesis, University of St. Andrews.

SCHÄFER, Manfred. 1991. "Ayompari 'el que me da las cosas': el intercambio entre los Ashéninka y Asháninka de la Selva Central peruana en perspectiva histórica". In: L. Malaver; M. Oostra \& P. Jorna (orgs.). Etnohistória del Amazonas. Quito: Abya-Yala. pp. 45-62.

TOCANTINS, Leandro. 1979. Formação Histórica do Acre. (Vol. 2). Rio de Janeiro: Civilização Brasileira.

TUZIN, Donald \& GREGOR, Thomas. 2001. Gender in Amazonia and Melanesia: an exploration of the comparative method. Berkley: University of California Press.

VARESE, Stefano. 2002. Salt of the Mountain. Campa Asháninka History and Resistance in the Peruvian Jungle. Norman: The University of Oklahoma Press.

VEBER, Hanne \& VIRTANEN, Pirjo (eds.). 2017. Creating Dialogues. Indigenous Perceptions and Changing 
Forms of Leadership in Amazonia. Boulder: University Press of Colorado. VILAÇA, Aparecida. 1999. "Devenir autre: chamanisme et contact interéthnique en Amazonie brésilienne". Journal de la Société des Américanistes, 85:239-260.

VIVEIROS DE CASTRO, Eduardo. 2002. "O problema da afinidade na
Amazônia". In: A inconstância da alma selvagem e outros ensaios de antropologia. São Paulo: Cosac e Naify. pp. 87-180.

WOLFF, Cristina. 1999. Mulheres da floresta: uma história. Alto Juruá - Acre (1890-1945). São Paulo: Hucitec. 


\section{AMOR REBELDE: HISTÓRIA, CASAMENTO E POLÍTICA NO ALTO JURUÁ}

\begin{abstract}
Resumo
Este artigo aborda um tipo de união matrimonial geralmente invisibilizado e provocador para o imaginário nacional brasileiro: o casamento interétnico entre uma mulher branca e um homem indígena. Baseia-se na análise de um caso ocorrido em meados dos anos 1960 no rio Amônia, na região acreana do Alto Juruá. Após refletir sobre a história dos Ashaninka nessa região de fronteira do Brasil com o Peru e mostrar a necessidade de repensar alguns lugares-comuns sobre a vinda desse povo indígena para o Alto Juruá brasileiro, o texto apresenta a trajetória de dois grupos familiares que se instalaram no rio Amônia na década de 1940. Mostra a singularidade desse matrimônio interétnico, discute seus significados, para os brancos da região e para os Ashaninka, e apresenta seus efeitos políticos. Sustenta a tese de que esse casamento é fundamental para entender o protagonismo e a visibilidade política dessa comunidade indígena no campo do indigenismo nas últimas duas décadas.
\end{abstract}

Palavras-chave: Ashaninka, Alto Juruá, História, Casamento, Política.

\section{REBELLIOUS LOVE: HISTORY, MARRIAGE AND POLITICS IN THE UPPER JURUÁ}

\section{Abstract}

This article focuses on a marital arrangement that is both rare and captivating in Brazil: the interethnic union between a white woman and an indigenous man. It analyses an interethnic marriage that occurred in the mid1960s on the Amonia River in the state of Acre. First, it briefly presents the history of the Ashaninka people on the Brazil-Peru border and calls for a reconsideration of certain commonplace notions about their arrival on the Brazilian side of the Upper Juruá River. Second, it describes the trajectory of two families, which settled on the Amonia River in the 1940s. Third, it reveals the specificities of the marriage between a son and a daughter of these two families, discussing its significance for the whites of the region and the Ashaninka, and demonstrating its political consequences. The paper argues that this marriage is central to understanding the protagonism and political visibility of the Amonia Ashaninka during the last two decades. Key words: Ashaninka, Upper Juruá, History, Marriage, Politics. 


\section{AMOR REBELDE: HISTORIA, MATRIMONIO Y POLÍTICA EN EL ALTO JURUÁ}

\section{Resumen}

Este artículo examina un tipo de unión matrimonial generalmente invisibilizado y provocador para el imaginario nacional brasileño: el matrimonio interétnico entre una mujer blanca y un hombre indígena. El análisis se enfoca en un caso que tiene lugar en la región del Alto Juruá en el estado de Acre, a mediados de la década de 1960. Después de reflexionar sobre la historia de los Asháninka en esta región de la frontera de Brasil con Perú, y de repensar algunos lugares comunes acerca de la llegada de este pueblo indígena al Alto Juruá, el texto describe la trayectoria de dos grupos familiares que se instalaron en el rio Amônia en la década de 1940. Posteriormente, se muestra la particularidad del matrimonio interétnico que une a dos miembros de estas familias, se discute los significados que tiene tanto para los blancos de la región como para los Asháninka, y los efectos políticos que acarrea. El artículo argumenta que este matrimonio es fundamental para entender el protagonismo y la visibilidad política de esta comunidad indígena en el campo del indigenismo en las últimas dos décadas.

Palavras-chave: Asháninka, Alto Juruá, Historia, Matrimonio, Política. 